\title{
Investigating Individual Learning Strategies Used by Jordanian
}

\section{EFL Students}

\author{
Sana' Ababneh ${ }^{1 *}$ \\ ${ }^{1}$ Al-Balqa' Applied University, Al-Salt, Jordan \\ *Sana'Ababneh, E-mail: sanabneh@yahoo.com
}

Received: October 16, 2017

Accepted: October 27, 2017 Online Published: November 1, 2017

doi:10.22158/selt.v5n4p657

URL: http://dx.doi.org/10.22158/selt.v5n4p657

\begin{abstract}
The present study investigated the use of individual learning strategies among Jordanian EFL university students. The study employed a quantitative method for collecting data involving mainly a questionnaire administration. Subjects of the study were 135 Jordanian students who study English and translation at Yarmouk University. The subjects of the study completed a questionnaire through which data were collected on their use of individual learning strategies. The obtained data were analyzed using the Statistical Package for Social Sciences (SPSS). The results revealed that most of the subjects were moderate users of the individual learning strategies. However, neither gender, nor major had a significant effect on the subjects' use of those strategies. The study also showed that the subjects' academic year level at the university had a significant effect in terms of their use of the strategies in favor of the seniors.
\end{abstract}

\section{Keywords}

EFL, individual learning strategies, learner's gender, Jordan

\section{Introduction}

The present paper deals with learning strategies in the context of EFL (English as a Foreign Language) Jordanian students for whom Arabic is the mother tongue (L1) and English is a foreign language (L2) which is very important for their education and their future career.

Learning strategies are defined by many scholars in the field (e.g., Griffiths, 2007; Brown, 2001; Richards, Platt, J., \& Platt, H., 1992; Wenden, 1991) who seem to agree with Oxford's (1990) definition of these strategies as "steps taken by students to enhance their own learning" (p. 1). Oxford goes on to assert that strategies are especially important for language learning because they are tools for active, self-directed involvement, which is essential for developing communicative competence. Appropriate language learning strategies result in improved proficiency and great self-confidence (p. 1).

In other words, language learning strategies play an influential role in the process of successful 
language acquisition.

There is a strong relation between success and the strategy used in different aspects of language learning (Macaro, 2006). Moreover, there are group differences and individual differences in the use of the learning strategy. For instance, sex and culture are good examples of group-defining parameters since the choice of strategy is affected by membership in these groups (Macaro, 2006). Individual differences arise because of differences among learners due to their different circumstances, abilities, etc. Learners are expected to develop their own conscious or unconscious strategies to master the material quite soon in their study (Willerman \& Melvin, 1979).

\section{Literature Review}

Since language learning strategies play an important part in second/foreign language acquisition, many studies have been conducted to explore them. For example, Wu (2000), Chen (2001) and Wang (2002) studied Taiwanese students' strategies; Nikoopour et al. (2011) and Gerami and Ghareh (2011) conducted their study on Iranian students; Alnufaie and Grenfell (2012) studied Saudi students; Saengpakdeejit (2014) investigated Thai students' strategies; and Al Khatib (2013) studied Emirati students. The details of all these studies are certainly of significance to the field but only a more relevant group with a more theoretical import will be presented here.

Oxford (1990) identifies six major groups of L2 learning strategies including cognitive, metacognitive and memory-related ones. Moreover, there are other psychological as well as social ones like asking questions, asking for clarifications and the like. The variety of these strategies stems from the nature of the complex tasks involved in the process of learning. As Brown (2001) puts it, "a language is probably the most complex set of skills one could ever seek to acquire; therefore, an investment is necessary in the form of developing multiple layers of strategies for getting that language into one's brain" (p. 208). Thus, it is essential for learners to use the right strategies that enable them to be good and successful language learners.

Studies in this field prove that good language learners and bad language learners both use strategies but in different ways. According to Cook (2001), people who are realized as good language learners might tackle learning in different ways from those who seem to be less good or they might behave in the same way but more efficiently. Stern (1983) agrees that good language learners are more likely to employ four basic sets of learning strategies while poor language learners weakly employ those strategies. First, good language learners select goals and sub-goals for their learning. Then they analyses the language and develop the right techniques of practicing and memorizing. They also seek a communicative contact with the target language users through speaking, writing, or media. Finally, effective language learners develop certain affective strategies to deal with the emotional or motivational obstacles which they may face in their language learning process. Brown (2001) stresses individual differences stating that good language learners can find their own way by taking charge of their own learning. Moreover, they can create their own opportunities for practice to use the language both inside and outside the 
classroom.

Rubin (1975) is most straightforward when he observes that strategies used by good language learners can be summarized as follows:

a) The good language learner is a willing and accurate guesser.

b) The good language learner has a strong drive to communicate, or to learn from a communication.

c) The good language learner is often not inhibited.

d) In addition to focusing on communication, the good language learner is prepared to attend to form.

e) The good language learner practices. He may practice pronouncing words or making up sentences.

f) The good language learner monitors his own and the speech of others.

g) The good language learner attends to meaning.

\section{Significance of the Study}

Part of the significance of the present study stems from the importance of learning such an important language as English. It is well acknowledged that there is a global demand for English language learning because it has become the language of international business, commerce, technology, media, tourism, and science (Ababneh \& Al-Momani, 2011). Thus, everyone needs to learn English to a certain degree to improve and enhance their profession. In some countries like Jordan English is the language in which many subjects such as medicine, engineering and science are taught (Carkin, 2005). Furthermore, learners can improve their English by using many individual learning strategies like watching English movies, songs and online shopping. The Internet is another venue for learning English since about 80\% of all World Wide Web sites around the world are in English (Brown, 2002). Chatting with native speakers of English through the virtual space and modern means of communication such as face book and twitter is yet another reason for people all over the world to know English.

Moreover, studies in the field of learning and teaching second or foreign languages revealed that language learning strategies are found to have a positive influence on language learning in its various aspects. For instance, these strategies could raise learners' consciousness and assist them in preventing, predicting, and tackling the problems in the process of language learning. The learners who use these strategies can manage their learning anxiety to a reasonable degree, and make progress in language learning more autonomously (Kamran, 2012).

The present study aims to shed light on those individual learning strategies used by Jordanian EFL students and to encourage English language teachers to advise learners to make use of such strategies wisely to improve their proficiency in English. This goes in the same vein with Richards, Platt and Platt (1992) who claim that the effectiveness of second language learning is thought to be improved by teaching learners more effective learning strategies. Moreover, to borrow Oxford's words: "appropriate 
language learning strategies result in improved proficiency and greater self-confidence" (1990, p. 1).

\section{Research Questions}

To achieve the set of goals of the study, the following questions were proposed in the study:

a) How often do EFL students use individual learning strategies to improve their English?

b) Are there any significant differences among students' responses to the questionnaire items due to the differences in their gender?

c) Are there any significant differences among students' responses to the questionnaire items due to the differences in their major?

d) Are there any significant differences among students' responses to the questionnaire items due to the differences in their university year level: "freshmen, sophomores, juniors or seniors"?

\section{Methodology}

This study was carried out to shed some light on the individual learning strategies used by Jordanian EFL students' in learning English as a foreign language. Furthermore, it aimed to investigate if there are any significant differences between those learning strategies between the respondents that could be attributed to the differences of their gender, academic major, or university level. To achieve this, the researcher adopted a questionnaire from Brown (2002) as a research tool.

\subsection{Participants}

The participants in this study were students in two different departments: The Department of Translation and the Department of English Language and Literature. They were registered in two introductory courses (one in semantics and the other in syntax) at the Department of English at Yarmouk University during the second semester of the academic year 2014/2015. The subjects were 117 female students and 18 male students. The discrepancy in the number of males and females is due to the overall population of the English Department and the Translation Department at Yarmouk University: both have more female students than male ones. The sections chosen for the study are not exceptions to this overall tendency and had more females.

All the students in the two sections filled the questionnaire designed to identify their individual strategies in learning English. The sample included different university year levels: freshmen, sophomores, juniors, and seniors. Table 1 shows the distribution of the participants. 
Table 1. Numbers and Percentages of the Participants of the Study

\begin{tabular}{llll}
\hline Variable & & Frequency & Percentage \\
\hline Gender & Male & 18 & 13.3 \\
& Female & 117 & 86.7 \\
& Total & 135 & 100.0 \\
Major & Translation & 73 & 54.1 \\
& English language \& literature & 62 & 45.9 \\
\multirow{3}{*}{ Academic year level } & Freshman & 135 & 100.0 \\
& Sophomore & 2 & 1.5 \\
& Junior & 10 & 7.4 \\
& Senior & 70 & 51.8 \\
& Total & 53 & 39.3 \\
& & 135 & 100.0 \\
\hline
\end{tabular}

\subsection{Instrument of the Study}

The main instrument of data collection of this study was a questionnaire which consisted of 16 statements. In front of each statement there are five choices which describe how often the students use those individual learning strategies in their life. The researcher adopted this questionnaire from Brown (2002, p. 54). The researcher wanted to identify the strategies used by Jordanian EFL students, as well as to examine the differences between those strategies that could be attributed to the difference in gender, university year level, or academic major.

All the items of the questionnaire were written in English and the students answered them in the presence of the researcher and their instructor who answered any inquiries that the respondents had about those items.

\subsection{Data Collection}

Before administering the questionnaire, permission was sought from the professor who taught the two courses and who also helped administer the questionnaire. Prior to distributing the questionnaire, the students were informed of the objectives and the significance of the research. They were also told that their responses would remain confidential. They were requested to state their true and honest responses. Moreover, they could ask for any clarifications they might need.

\subsection{Data Analysis Procedures}

The total average mean scores and the standard deviations of the students' responses on each statement were computed to find out how often they use the individual learning strategies in their process of learning English. Moreover, students' responses to the questionnaire were analyzed to see if there were any significant differences between their responses that could be due to the difference in the gender, academic major or the university year level of the students by using SPSS program. The T-test was 
used to see if there are differences between the students' use of strategies that could be attributed to the difference in gender and major. On the other hand, the ANOVA-test was used to study the effect of the university year level on the choice of strategy.

\section{Findings and Discussion}

The first question that this study aimed to answer is how often the respondents resort to the use of individual learning strategies to improve their English. Based on the answers to the Questionnaire, the respondents could be divided into three categories according to their use of the individual learning strategies: those who "seldom" use these strategies; those who "sometimes" use them; and those who "often" do. Table 2 below shows that most of the respondents, $77.8 \%$, resorted to the use of individual learning strategies only "sometimes" while $20 \%$ used them "often" and only $2.2 \%$ "seldom" used those strategies.

Table 2. Frequency and the Percentage of Respondents Use of the Individual Learning Strategies

\begin{tabular}{lll}
\hline & F & $\%$ \\
\hline Seldom & 3 & 2.2 \\
Sometimes & 105 & 77.8 \\
Often & 27 & 20.0 \\
Total & 135 & 100.0 \\
\hline
\end{tabular}

The second question sought to find out whether there were any significant differences between the respondents' use of the individual learning strategies that could be attributed to the difference in their gender. To achieve this, the researcher did a t-test of equality between the mean scores of the respondents according to their gender. Table 3 shows this.

Table 3. Mean Scores and T-Test of Respondents' Use of the Individual Learning Strategies Presented in the Questionnaire According to Their Gender

\begin{tabular}{lllll}
\hline & Mean scores & Std. Deviation & T & Sig. \\
\hline Male & 55.22 & 8.80 & & \\
& & & 0.86 & 0.39 \\
Female & 56.87 & 7.35 & & \\
\hline
\end{tabular}

Results obtained from Table 3 show that the $t$ value was 0.86 . This indicates that there are no significant differences between the respondents' responses to the questionnaire statements that could be due to the difference in their gender.

The third question of this study aimed at investigating the effect of the academic major (Translation vs. 
English Language and Literature) on the respondents' frequency of using the strategies under study. To obtain this goal, the researcher did a t-test of equality between the mean scores of the respondents according to their academic major. Table 4 below presents this.

Table 4. Mean Scores and T-Test of Respondents' Use of the Individual Learning Strategies Presented in the Questionnaire According to Their Academic Major

\begin{tabular}{lllll}
\hline Major & Mean scores & Std. Deviation & T & Sig. \\
\hline Translation & 56.18 & 7.28 & 0.79 & 0.43 \\
English Language and Literature & 57.21 & 7.87 & & \\
\hline
\end{tabular}

The data presented in Table 4 show that the $t$ value was 0.79 . This indicates that there are no significant differences between the subjects' responses due the difference in their academic major.

The fourth question of this study seeks to explore whether the differences between the respondents' university year level (freshman, sophomore, junior or senior) had any significant influence on their use of the strategies. To answer this question, the researcher computed the mean scores and the standard deviations of the respondents' responses then applied the ANOVA analysis. Table 5 shows the results.

Table 5. Results of the ANOVA Analysis of the Means of the Respondents' Use of the Individual Learning Strategies Presented in the Questionnaire According to Their Academic Year Level

\begin{tabular}{lllll}
\hline Academic year level & Mean scores & Std. deviation & F & Sig. \\
\hline Freshman & 50.00 & 11.31 & & \\
Sophomore & 56.70 & 5.44 & & \\
Junior & 55.10 & 7.74 & 3.30 & 0.02 \\
Senior & 58.94 & 7.01 & & \\
\hline
\end{tabular}

The results in Table 5 show that the F. value was 3.30. This indicates that there were significant differences due to the academic year level between the respondents. To explore the source of differences, Post Hoc Tests (Scheffe) were computed. Table 6 shows that.

Table 6. Results of the Post Hoc Tests (Scheffe) According to the Differences in the Respondents' Academic Year Level

\begin{tabular}{llllll}
\hline Academic year level & Mean & Freshman & Sophomore & Junior & Senior \\
\hline Freshman & 50.00 & & -6.7 & -5.1 & $-8.94^{*}$ \\
Sophomore & 56.70 & & & 1.6 & $-2.24^{*}$ \\
Junior & 55.10 & & & & $-3.84^{*}$ \\
Senior & 58.94 & & & & \\
\hline
\end{tabular}

*Statistically significant. 
The results in Table 6 show that the source of variance was due to the last category, the seniors. This result is meaningful and could be explained by the fact that the seniors had been exposed more than the other three categories to English and, therefore, they were more experienced in using individual strategies to improve their English.

\section{Conclusion and Recommendations}

Many conclusions could be drawn from the findings of this study. First, most Jordanian students use individual learning strategy to enhance their learning of English as a foreign language only some of the time while $20 \%$ are frequent users of those strategies in their learning process; only $2.2 \%$ are seldom users of those strategies. These findings go in line with the results of Al Khatib's (2013) study where the findings indicated that the subjects were sometimes strategy users. It is also in line with Nikoopour et al. (2011) whose findings revealed that, in terms of overall strategy use, Iranian EFL learners were, in general, sometimes strategy users. This finding could explain the fact that most Jordanian EFL students are weak in English and find it difficult to learn because they do not resort to the use of the learning strategies that would help them become more successful.

Secondly, the data also show that gender had no significant effect on the participants' use of learning strategies. This result is in the same vein with the results of Al Khatib (2013) who found that gender had no significant effect on strategy use of Emirati EFL learners. Thirdly, the data also prove that the academic university major of the participants had no significant influence on their use of the learning strategies. This result might be explained by the fact that the participants enjoy the same background in English.

Finally, the data show that the academic year level of the subjects (i.e., whether they were freshmen, sophomores, juniors or seniors) had a significant effect on the subjects use of the learning strategies in favor of the seniors over the other three levels since they enjoy more experience in practicing English and they were more exposed to English than their colleagues. It is worth mentioning here that, most of the respondents in this study as well as the other students who are studying English in Jordan, do not frequently use English as a medium for communication outside the classroom. This should explain why the seniors used more learning strategies than the others. This is simply since they have more opportunities to use English as they are more exposed to English than the other students.

Based on the literature in the field, which emphasizes the role of learning strategies in the learners' achievement, and the findings of the present study, it is recommended that Jordanian English language teachers raise their students' awareness of the important role of language learning strategies in English classes. They should detect their students' language learning strategies and help them in the problematic areas in their strategy preference and use. This is supported by Oxford (1990) who assumes that to help students learn better, teaching agendas would have to focus systematically on raising students' awareness of language learning strategies.

In addition, language curricula should include activities that help students become aware of language 
learning strategies in the in the manner suggested by Kinoshita (2003) who calls for integrating language learning strategy instruction into ESL/EFL classrooms because it not only helps learners become more efficient in their efforts to learn a second or foreign language, but it also provides a meaningful way to focus one's teaching efforts on a specific target efficiently. Moreover, "direct instruction in how, when and why to use language learning strategies" is recommended as part of classroom activities because this "can help learners in the systematic use of various strategies as they learn a second or foreign language", to borrow Cohen's words (1998, p. 96). Both Zare (2012) and Oxford (1990) agree with Cohen in this regard. Oxford (1990, p. 10) asserts that in addition to the other roles of a language teacher, she/he should assume new responsibilities "that include identifying students' learning strategies, conducting training on learning strategies, and helping learners become more independent". One of the benefits of this, Oxford (ibid.) adds, is that "[w]hen students take more responsibility, more learning occurs, and both teachers and learners feel more successful” (p. 11).

\section{References}

Ababneh, S., \& Al-Momani, M. (2011). The effect of a vocational instructional program on vocational students' English language proficiency. International Journal of Vocational Education and Training, 19, 53-66.

Al Khatib, A. Z. (2013). Language learning strategies of EFL students in the University General Requirements Unit in the United Arab Emirates University (M.A. Thesis).

Alnufaie, M., \& Grenfell, M. (2012). EFL students' writing strategies in Saudi Arabian ESP writing classes: Perspectives on learning strategies in self-access language learning. Studies in Self-Access Learning Journal, 3(4), 407-422.

Brown, H. D. (2001). Teaching by principles: An interactive approach to language pedagogy (2nd ed.). White Plains, NY: Longman.

Brown, H. D. (2002). Strategies for success: A practical guide to learning English. White Plains, NY: Longman.

Carkin, S. (2005). English for academic purposes. In E. Hinkel (Ed.), A handbook of research in second language teaching and learning (pp. 85-98). New Jersey: Lawrence Elbaum Associates.

Chen, I. (2001). Language learning strategies used by high and low English proficiency students in a technology college (Unpublished thesis). National Changhua University of Education, Changhua, Taiwan.

Cohen, A. D. (1998). Strategies in learning and using a second language. London: Longman.

Cook, V. (2001). Second language learning and language teaching (3rd ed.). London: Arnold Publishers.

Gerami, M. H., \& Baighlou, S. M. G. (2011). Language learning strategies used by successful and unsuccessful Iranian EFL students. Procedia - Social and Behavioral Sciences, 29, 1567-1576. https://doi.org/10.1016/j.sbspro.2011.11.399 
Griffiths, C. (2007). Language learning strategies: Student's and teacher's perceptions. ELT Journal, 61(2), 91-99. https://doi.org/10.1093/elt/ccm001

Kamran, S. K. (2012). Language Learning Strategy (LLS) in EFL classroom. Humanising Language Teaching, 14(5).

Kinoshita, C. Y. (2003). Integrating language learning strategy instruction into ESL/EFL lessons. The Internet TESL Journal, IX(4).

Macaro, E. (2006). Strategies for language learning and for language use: Revising the theoretical framework. The Modern Language Journal, 90(3), 320-337. https://doi.org/10.1111/j.1540-4781.2006.00425.x

Nikoopour, J., Farsani, M. A., \& Neishabouri, J. K. (2011). Language learning strategy preferences of Iranian EFL students. IPEDR, 5(2).

Oxford, R. L. (1990). Language learning strategies: What every teacher should know. New York: Newburry House.

Richards, J. C., Platt, J., \& Platt, H. (1992). Language teaching and applied linguistics. London: Longman.

Rubin, J. (1975). What the "good language learners" can teach us. TESOL Quarterly, 9(1), 41-51. https://doi.org/10.2307/3586011

Saengpakdeejit, R. (2014). Awareness of vocabulary learning strategies among EFL students in Khon Kaen University. Theory and Practice in Language Studies, 4(6), 1101-1108. https://doi.org/10.4304/tpls.4.6.1101-1108

Stern, H. H. (1983.) Fundamental concepts of language teaching. Oxford: Oxford University Press.

Wang, W. (2002). Effects of gender and proficiency on listening comprehension strategy use 274 by Taiwanese EFL senior high school students: A case from Changhua, Taiwan (Unpublished M.A. thesis). National Changhua University of Education, Chanhua, Taiwan.

Wenden A. L. (1991). Learner strategies for learner autonomy. New York: Prentice-Hall.

Willerman, B., \& Melvin, B. (1979). Reservations about the keyword mnemonic. Canadian Modern Language Review, 35, 443-453.

Wu, R. (2000). Exploring language learning strategies. Min-Chung Japanese Education Report, 3, 109-126.

Zare, P. (2012). Language learning strategies among EFL/ESL learners: A review of literature. International Journal of Humanities and Social Science, 2(5), 162-169. 